\title{
An Investigation into the Mode of Action of Actinonin
}

\author{
By MARGARET M. ATTWOOD \\ Department of Microbiology, University of Sheffield
}

(Accepted for publication 24 September 1968)

\begin{abstract}
SUMMARY
The mode of action of actinonin, a pseudo-peptide antibiotic has been investigated. When added to cultures of Bacillus subtilis 7198 and $36 \mathrm{IO}$ actinonin inhibits growth. Evidence is presented which shows that this inhibition of growth reflects a bacteriostatic rather than bactericidal effect and that the site of action of the antibiotic is associated with RNA synthesis.
\end{abstract}

\section{INTRODUCTION}

The antibiotic antinonin first obtained from the culture filtrates of a Streptomyces species classified as Streptomyces sp. CUTTER C/2 NCIB 8845 (Gordon, Kelly \& Miller, 1962) has been shown to have the constitutional formula of the pseudo-peptide shown in Fig. I (Ollis, East, Gordon \& Sutherland, I964). As a natural product this structure is of interest since it is the first known naturally occurring derivative of L-prolinol and is also the first known naturally occurring hydroxamic acid of the type $\mathrm{R}-\mathrm{CO}-\mathrm{NHOH}$. Actinonin shows some structural relationship to other polypeptide antibiotics but it

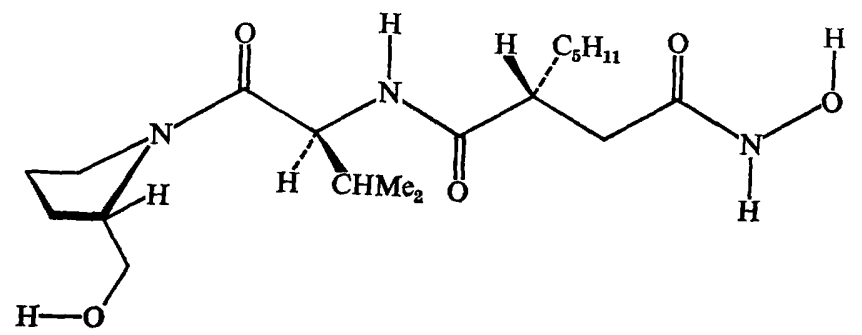

Fig. I. The constitution of actinonin.

contains no $\mathrm{D}-\alpha$-amino acid residue. This absence of $\mathrm{D}-\alpha$-amino acid residues in association with antibiotic activity should be considered in relation to the idea put forward by Arnstein (1957) that amongst the polypeptide antibiotics the minimum requirement for biological activity is the presence of one amino acid residue with the D-configuration. Actinonin has been shown to be active against, in the main, Grampositive bacteria, with some evidence of activity against Gram-negative bacteria, the acid-fast bacteria and a number, of phage strains (Gordon et al. 1962). This wide and in some instances unusual biological activity coupled with its chemical stability and low toxicity makes actinonin an interesting antibiotic. This work describes investigations directed towards an understanding of the mode of action of actinonin. 


\section{METHODS}

Organisms and growth conditions. The organisms used in this investigation were Bacillus subtilis (NCJB 7198) and B. subtilis (NCIB 36I0).

The bacteria were grown overnight at $30^{\circ}$ with constant shaking in a defined medium of Davis mineral medium (Davis \& Mingioli, 1960) supplemented with L-asparagine and L-glutamic acid (Io $\mu \mathrm{g}$. $/ \mathrm{ml}$.). Bacteria from this suspension were used to inoculate fresh medium and the growth of the bacteria was followed by measuring the extinction of the suspension in a Unicam SP 600 at $610 \mathrm{~m} \mu$. Any additions to the system were made at the end of the lag period of bacterial growth unless otherwise stated. Actinonin was always added as an aqueous solution and was stable under the experimental conditions.

Viable counts were made in triplicate on the defined medium plus agar $(\mathrm{I} \cdot 5 \%, \mathrm{w} / \mathrm{v})$ using the surface-spreading method after serial dilution of the bacteria in saline to ensure that 100 to 200 bacteria were distributed on each plate.

Synthesis of cellular constituents. (I) Net synthesis of cellular RNA,DNA and protein. Suspensions of Bacillus subtilis 7198 were incubated at $30^{\circ}$ with shaking in the defined medium in the presence and absence of actinonin. Samples $(3 \mathrm{ml}$.) were taken at intervals and cooled rapidly. The bacteria were harvested by centrifugation and washed with a buffered salt solution. The bacterial pellet was extracted three times with $0.2 \mathrm{~N}$-perchloric acid at $4^{\circ}$ for $60 \mathrm{~min}$. and the supernatant fluids from the extractions combined. This constituted the bacterial pool fraction. The nucleic acids were extracted from the pellet with $0.5 \mathrm{~N}$-perchloric acid $\left(3 \mathrm{ml}\right.$.) at $70^{\circ}$ for $15 \mathrm{~min}$. Three extractions were required.

The RNA was estimated by the orcinol method (Schneider, 1957) and the DNA by the diphenylamine method of Burton (1956). The residual pellet was taken up in $\mathrm{N}-\mathrm{NaOH}$ and the protein present estimated by the method of Lowry, Rosebrough, Farr \& Randall (I95I). All estimations were performed in triplicate and gave an accuracy of $\pm 5 \%$.

(2) The production of bacteriophage infection centres. Bacillus subtilis 3610 growing exponentially in nutrient broth was harvested when a titre of $2 \times 10^{8}$ bacteria $/ \mathrm{ml}$. was obtained and then infected with phage $ø \mathrm{E}$ at a multiplicity of three. The mixture was shaken and incubated for $15 \mathrm{~min}$. at $30^{\circ}$ to allow the phage to become absorbed to the bacteria. The infected suspension was then centrifuged (5000 g) and the excess free phage particles removed with the supernatant fluid. The bacteria were resuspended in nutrient broth and diluted $4 \times 10^{5}$-fold with fresh growth medium. The latent period of the phage infection in this system is 70 to $80 \mathrm{~min}$. Actinonin at concentrations subinhibitory to bacterial growth was added or removed at various times throughout the latent period. Samples were taken at the end of the latent period and assayed for total infective centres (plaque formers) by the procedure described by Adams (I959).

\section{RESULTS}

The effect of actinonin upon the viability of Bacillus subtilis 7198. The limiting growth inhibitory concentration for $B$. subtilis 7198 under these conditions was seen to be $2 \mathrm{mg}$. $/ \mathrm{ml}$. At this concentration the effect was bacteriostatic rather than bactericidal. The results are shown in Table $\mathrm{I}$. 
Resistance of Bacillus subtilis to repeated additions of actinonin. Bacteria grown in the presence of actinonin for $24 \mathrm{hr}$ or more were resistant to further treatment with actinonin (Fig. 2) but had a slower growth rate than the untreated control bacteria. No information has been obtained from which the possible mechanism of this resistance could be ascertained.

Respiration and fermentation. Actinonin (at 100,1000 and $3000 \mu \mathrm{g} . / \mathrm{ml}$.) had no effect on endogenous respiration, oxidation of glucose or anaerobic fermentation of glucose when added to washed suspensions of Bacillus subtilis 7198 in Warburg vessels. These studies were made by the standard manometric techniques (Umbreit, Burris \& Stauffer, I964).

Permeability and integrity of the cell membrane. Bacteria previously grown in a rich medium were suspended in buffer in the presence and absence of actinonin

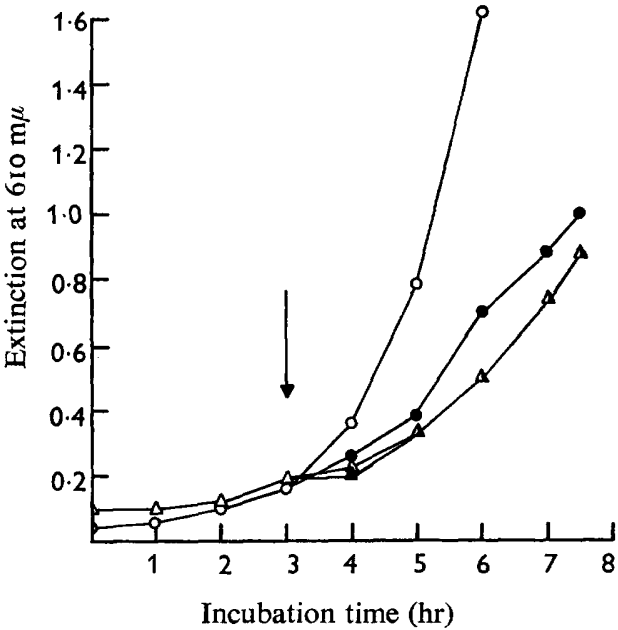

Fig. 2

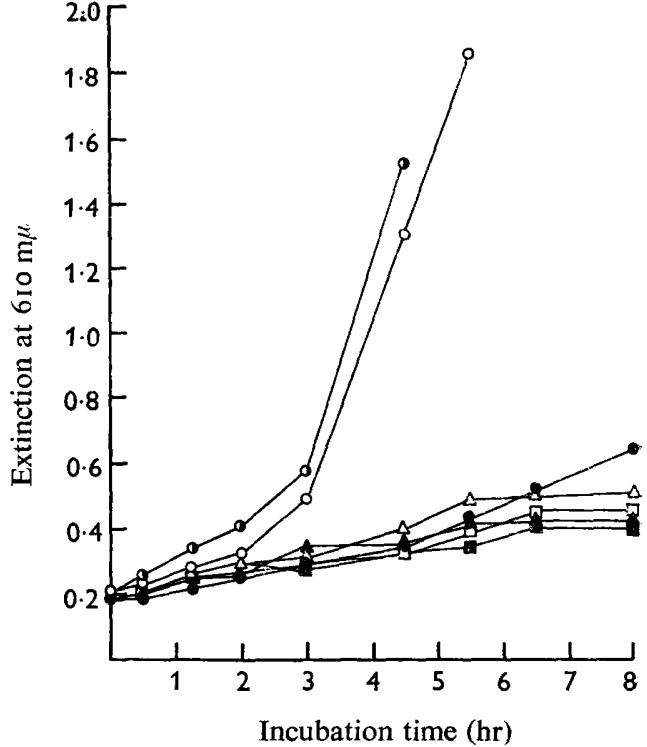

Fig. 3

Fig. 2. The resistance of 'actinonin pretreated' Bacillus subtilis 7 I 98 to further treatment with actinonin. A suspension of $B$. subtilis 7198 was grown in defined medium containing actinonin (100 $\mu \mathrm{g} . / \mathrm{ml}$.) for $24 \mathrm{hr}$. This culture became the 'pretreated' inoculum. Another suspension of $B$. subtilis 7198 was grown in defined medium alone for $24 \mathrm{hr}$-this culture became the control inoculum. Both types of inoculum were then used to inoculate fresh medium alone ( $O-O$, control inoculum; and $\triangle-\triangle$, pretreated inoculum). After $3 \mathrm{hr}$ incubation (at arrow) actinonin ( $100 \mu \mathrm{g} . / \mathrm{ml}$. final conc.) was added to one of the control inoculum cultures $(-\mathbf{O})$ and to one of the pretreated cultures $(\boldsymbol{\Delta}-\mathbf{A})$. Growth was followed as described in the Methods section. When actinonin (100 $\mu \mathrm{g} . / \mathrm{ml}$.) was added to the pretreated inoculum (A- $\mathbf{A})$ growth of this sample and the control pretreated inoculum was identical $(\boldsymbol{\Delta}-\boldsymbol{\Delta})$.

Fig. 3. The effect of adding $\mathrm{Mg}^{2+}$ ions to a suspension of Bacillus subtilis 7198 growing in the presence of actinonin. A suspension of $B$. subtilis 7198 was incubated at $30^{\circ}$ in the defined medium containing actinonin (100 $\mu \mathrm{g} . / \mathrm{ml}$ ) and $100 \mu \mathrm{g}$. $\mathrm{Mg}^{2+}$ ions $/ \mathrm{ml} .(\triangle-\triangle) ; 200 \mu \mathrm{g}$.

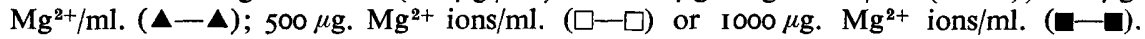
Control suspensions of $\boldsymbol{B}$. subtilis were incubated in the defined medium alone $(\mathrm{O}-\mathrm{O})$; defined medium with $1000 \mathrm{Mg}^{2+}$ ions $/ \mathrm{ml} .(\mathrm{O}-\mathrm{O})$ and defined medium containing actinonin ( $100 \mu \mathrm{g} . / \mathrm{ml}$.) only (-) The growth was followed as described in the Methods section. 
(100 and $1000 \mu \mathrm{g} . / \mathrm{ml}$.). The rate of release of amino acids, purines and pyrimidines from the bacteria into the medium was measured (Gale \& Taylor, I947). There was no evidence of increased permeability of the bacteria to these molecules in the presence of the antibiotic.

Chelation and antimetabolite studies. The addition of the metal ions $\mathrm{Mg}^{2+}, \mathrm{Mn}^{2+}, \mathrm{Fe}^{2+}$, $\mathrm{K}^{+}$and $\mathrm{Ca}^{2+}$ (o to $1000 \mu \mathrm{g}$. $/ \mathrm{ml}$.), the amino acids L-valine and L-isoleucine, D-alanine or L-aspartic acid (o to $500 \mu \mathrm{g}$. $/ \mathrm{ml}$.) to bacteria growing in the presence of actinonin failed to annul the growth inhibitory effect of the antibiotic. Figure 3 shows<smiles>CCCCC(CC(=O)NOCc1ccccc1)C(=O)NC(C)C(=O)N1CCCCC1</smiles>

Fig. 4. The constitution of $O$-benzylactinonin.

Table I. Viability of Bacillus subtilis 7198 grown in the presence of increasing concentrations of actinonin

B. subtilis $\left(6 \times 10^{6}\right.$ bacteria $/ 5 \mathrm{ml}$.) was incubated at $30^{\circ}$ for up to $4 \mathrm{hr}$ in the defined medium. Actinonin in sterile distilled water was added in the concentrations shown at the beginning of the incubation period. Samples ( $0.1 \mathrm{ml}$.) were taken at the times indicated below and plated out in triplicate on to defined media as described in the Methods section and incubated for $24 \mathrm{hr}$ at $30^{\circ}$. The colonies formed were then counted. Accuracy obtained was $\pm 5 \%$.

$$
\begin{gathered}
\text { Actinonin } \\
\text { added } \\
\text { (mg./ml.) }
\end{gathered}
$$

$\left.\begin{array}{c}0 \\ 0.1 \\ 1 \cdot 0 \\ 2 \cdot 0 \\ 3 \cdot 0\end{array}\right\}$

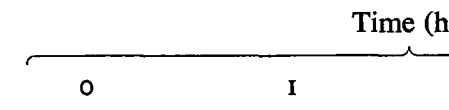

$6 \times 10^{6} \quad\left\{\begin{array}{l}7 \cdot 3 \times 10^{6} \\ 6 \cdot 2 \times 10^{6} \\ 5 \cdot 9 \times 10^{6} \\ 6 \cdot 1 \times 10^{6} \\ 6.1 \times 10^{6}\end{array}\right.$

2

$1 \cdot 2 \times 10^{7}$

$8.0 \times 10^{6}$

$6.6 \times 10^{6}$

$6.4 \times 10^{6}$

$6.0 \times 10^{6}$

\section{3}

$3.7 \times 10^{7}$

$2 \cdot 2 \times 10^{7}$

$1.8 \times 10^{7}$

$6.2 \times 10^{6}$

$5.7 \times 10^{6}$

Table 2. Growth inhibitory effect of actinonin and O-benzylactinonin on a culture of Bacillus subtilis 7198 growing in the test system

Organisms were grown in defined medium in Monod flasks in presence of compound under test. The concentration of compounds varied from 100 to $2000 \mu \mathrm{g}$. $/ \mathrm{ml}$. Growth was measured at $610 \mathrm{~m} \mu$. Inhibition was calculated as the percentage of the growth measured in the absence of any added compound.

$\%$ growth inhibition after $3 \mathrm{hr}$ incubation in

$\begin{array}{lc} & \text { Concn. } \\ \text { Compound added } & (\mu \mathrm{g} . / \mathrm{ml} .) \\ \text { Actinonin } & 100 \\ & 1000 \\ O \text {-Benzylactinonin } & 500 \\ & 1000 \\ & 2000\end{array}$
presence of test compound 
the results obtained using $\mathrm{Mg}^{2+}$ ions. Identical relationships were seen when the other additions were made to the system. Furthermore, the addition of a synthetic analogue of actinonin, $O$-benzylactinonin (kindly supplied by Mr J. P. Devlin) consistently and reproducibly produced an inhibition of bacterial growth. Results shown in Table 2. This analogue has the free hydroxamic acid residue blocked by the benzyl group (see Fig. 4).

Synthesis of cellular constituents. An investigation during the first $75 \mathrm{~min}$. of growth after the addition of the antibiotic shows that the total synthesis of RNA and protein are inhibited (Table 3), but that DNA synthesis is not significantly affected. However, the initial site of action of the antibiotic appears to be associated with RNA synthesis since a significant reduction of total RNA is evident after 15 min. incubation, whereas a reduction in total protein is only evident after $30 \mathrm{~min}$. incubation.

\section{Table 3. The effect of actinonin upon the growth and total synthesis of protein, RNA and DNA of Bacillus subtilis}

Six Monod flasks containing defined medium were inoculated with B. subtilis 7 I 98 and incubated with shaking until the exponential growth phase was established (O.D. 0.405 at 6ro $\mathrm{m} \mu$ which gave a dry wt of $6.6 \mathrm{mg} . / 3 \mathrm{ml}$. sample). To one set of three flasks actinonin was added in aqueous solution to give a final concentration of $\mathrm{I} \mathrm{mg} . / \mathrm{ml}$, to the other remaining three flasks an equal volume of sterile distilled water was added. The flasks were then returned to the water bath $37^{\circ}$ and incubated with shaking. At intervals of $15 \mathrm{~min}$. growth was measured (see Methods section) and samples $(3 \mathrm{ml}$.) taken and the total protein, RNA and DNA estimated (see Methods section).

\begin{tabular}{|c|c|c|c|c|c|c|c|c|}
\hline \multirow[b]{2}{*}{$\begin{array}{l}\text { Time } \\
\text { (min.) }\end{array}$} & \multicolumn{2}{|c|}{ Growth } & \multicolumn{2}{|c|}{ Total protein (mg.) } & \multicolumn{2}{|c|}{ Total RNA (mg.) } & \multicolumn{2}{|c|}{ Total DNA (mg.) } \\
\hline & $\begin{array}{l}\text { - Acti- } \\
\text { nonin }\end{array}$ & $\begin{array}{l}\text { + Acti- } \\
\text { nonin }\end{array}$ & $\begin{array}{l}\text { - Acti- } \\
\text { nonin }\end{array}$ & $\begin{array}{l}\text { + Acti- } \\
\text { nonin }\end{array}$ & $\begin{array}{c}\text { - Acti- } \\
\text { nonin }\end{array}$ & $\begin{array}{c}\text { +Acti- } \\
\text { nonin }\end{array}$ & $\begin{array}{c}\text { - Acti- } \\
\text { nonin }\end{array}$ & $\begin{array}{l}\text { + Acti- } \\
\text { nonin }\end{array}$ \\
\hline 0 & 0.41 & $0.4 \mathrm{I}$ & $3 \cdot 30$ & $3 \cdot 30$ & $\mathrm{I} \cdot 05$ & $1 \cdot 05$ & 0.15 & 0.15 \\
\hline 15 & 0.52 & 0.52 & $3 \cdot 84$ & $3 \cdot 80$ & $1 \cdot 32$ & $1 \cdot 20$ & 0.15 & 0.14 \\
\hline 30 & 0.64 & 0.63 & 4.50 & $4 \cdot 29$ & $\mathrm{I} \cdot 56$ & $1 \cdot 22$ & 0.15 & 0.15 \\
\hline 45 & 0.77 & 0.71 & $5 \cdot 43$ & 5.01 & $\mathrm{I} \cdot 87$ & $I \cdot 3 I$ & 0.17 & 0.16 \\
\hline 60 & 0.92 & 0.75 & $6 \cdot 45$ & $5 \cdot 60$ & $2 \cdot 28$ & $\mathrm{I} \cdot 37$ & 0.29 & 0.28 \\
\hline 75 & $I \cdot 10$ & 0.89 & $7 \cdot 29$ & $5 \cdot 63$ & $2 \cdot 43$ & $I \cdot 42$ & 0.31 & 0.29 \\
\hline
\end{tabular}

Table 4. The percentage inhibition of formation of infective centres caused by addition of actinonin to the Bacillus subtlis 36ro/phage $ø$ E system

Phage particles were allowed to adsorb and infect the bacteria: (A) After increasing time intervals actinonin was added to the system and the incubation continued (see Methods section). (B) Immediately after phage infection actinonin was added and removed by dilution at time intervals throughout the latent period (see Methods section). In both cases at the end of the latent period the bacterial suspensions were analysed for infective centre formation.

$\begin{array}{cccc}\begin{array}{c}\text { A. Time when } \\ \text { actinonin added } \\ \text { (min.) }\end{array} & \begin{array}{c}\% \text { inhibition of } \\ \text { infective centre } \\ \text { production }\end{array} & \begin{array}{c}\text { B. Time when } \\ \text { actinonin removed } \\ \text { (min.) }\end{array} & \begin{array}{c}\% \text { inhibition of } \\ \text { infective centre } \\ \text { production }\end{array} \\ 0 & 98 & 0 & - \\ 10 & 98 & 10 & 57 \\ 20 & 97 & 20 & 67 \\ 30 & 98 & 30 & 57 \\ 40 & 98 & 40 & 57 \\ 50 & - & 50 & 57 \\ 60 & 95 & 60 & 79 \\ 70 & - & 70 & 74\end{array}$


Effect of actinonin upon the production of infective phage centres in Bacillus subtilis 3610 phage $ø$ E system. The addition of actinonin, only for the adsorptive period for the phage, showed that the antibiotic did not inhibit phage adsorption. Further studies during which actinonin was added: (a) at intervals throughout the adsorption period, and $(b)$ for increasing time into the latent period before being removed from the system, demonstrated that actinonin affected some process which occurred during the first Io min. of the latent period. Moreover, if the actinonin was not added until after an increasing time interval during the latent period and then left in the system for the rest of the latent period, the antibiotic affected some process which occurs late in the latent period. These results are shown in Table 4. When other antibiotics whose site of action have been reported were added to the system in such a manner and the results compared with those obtained for actinonin (Table 5), actinonin was shown to resemble actinomycin-D rather than chloramphenicol or 5 -aminoacridine.

Table 5. (A) Percentage inhibition of formation of infective centres caused by the addition of growth inhibitory substances at time intervals throughout the latent period after infection. Bacillus subtilis $36 \mathrm{ro} /$ phage $\sigma E$ system

Bacteria were infected with phage particles and after increasing time intervals growth inhibitory substances were added to the system and the incubation continued (see Methods section). At the end of the latent period the cell suspensions were analysed for infective centre formation.

$\begin{array}{ccccc}\begin{array}{c}\text { Time when } \\ \text { substance } \\ \begin{array}{c}\text { added } \\ \text { (min.) }\end{array}\end{array} & \begin{array}{c}\text { Actinomycin-D } \\ (\mathrm{I} \mu \mathrm{g} . / \mathrm{ml} .)\end{array} & \begin{array}{c}5^{\prime} \text {-Aminoacridine } \\ (20 \mu \mathrm{g} . / \mathrm{ml} .)\end{array} & \begin{array}{c}\text { Chloramphenicol } \\ (\mathrm{I} 00 \mu \mathrm{g} . / \mathrm{ml} .)\end{array} & \begin{array}{c}\text { Actinonin } \\ (\mathrm{I} 00 \mu \mathrm{g} . / \mathrm{ml} .)\end{array} \\ 0 & 99 & 100 & 97 & 98 \\ 10 & 99 & 92 & 91 & 98 \\ 20 & 97 & 95 & 80 & 97 \\ 30 & 95 & 98 & 46 & 98 \\ 40 & 96 & 87 & 50 & 98 \\ 50 & 97 & 74 & -43 & 95 \\ 60 & 95 & 46 & 54 & 7 \mathrm{I}\end{array}$

(B) Percentage inhibition of formation of infective centres caused by addition of growth inhibitory substances during adsorption of the phage and then removed at time intervals throughout the latent period. Bacillus subtilis $3610 /$ phage $ø$ E system

Bacteria were infected with phage particles and immediately the growth inhibitory substances were added (see Methods section). At time intervals throughout the latent period the inhibiting substances were removed from the infected cells by dilution and incubation continued. At the end of the latent period the cells were analysed for infective centre formation.

$\begin{array}{ccccc}\begin{array}{c}\text { Time when } \\ \begin{array}{c}\text { substance } \\ \text { removed } \\ \text { (min.) }\end{array}\end{array} & \begin{array}{c}\text { Actinomycin-D } \\ (\mathrm{I} \mu \mathrm{g} . / \mathrm{ml} .)\end{array} & \begin{array}{c}5^{\prime} \text {-Aminoacridine } \\ (20 \mu \mathrm{g} . / \mathrm{ml} .)\end{array} & \begin{array}{c}\text { Chloramphenicol } \\ (100 \mu \mathrm{g} . / \mathrm{ml} .)\end{array} & \begin{array}{c}\text { Actinonin } \\ (\mathrm{I} 00 \mu \mathrm{g} . / \mathrm{ml} .)\end{array} \\ \text { I0 } & 8 \mathrm{I} & 0 & 0 & 57 \\ 20 & 94 & 0 & 0 & 67 \\ 30 & 85 & 76 & 52 & 57 \\ 40 & 100 & 76 & 44 & 57 \\ 50 & 87 & 83 & 100 & 57 \\ 60 & 100 & 9 \mathrm{I} & 100 & 79 \\ 70 & 94 & 80 & 96 & 74\end{array}$




\section{DISCUSSION}

When the structure of actinonin with its free hydroxamic acid residue is considered the failure to reverse the inhibitory action of actinonin by the addition of metal ions to the system is both interesting and surprising. This is further emphasized by the reports that the growth inhibitory action of aspergillic acid, a cyclic hydroxamic acid, has been reversed by the addition of ferrous ions (Goth, 1945). Furthermore, as a hydroxamic acid derivative there is some structural similarity between actinonin, D-cycloserine and Hadacidin (Fig. 5). Thus from these structural considerations it appeared possible that the biological activity of actinonin could involve an antimetabolite/essential metabolite relationship. However, the addition of the respective essential metabolites D-alanine and L-aspartic acid failed to annul the growth inhibitory effect of actinonin. Hogg, Biswas \& Broquist (1965) reported that cyclic<smiles>CCCCC(C)(CC(=O)NO)NC(=O)C(C)C</smiles><smiles>NC1CONC1=O</smiles><smiles>O=C(O)C[N+]([O-])=C(O)C(=O)N(O)C(=O)O</smiles>

Fig. 5. The constitution of actinonin (A), D-cycloserine (B) and Hadacidin (C).

hydroxamic acids inhibited the growth of Escherichia coli by interfering with the biosynthesis of L-valine and L-isoleucine. They showed that the toxicity of cyclic hydroxamates could be counteracted by the addition of mixtures of $L$-valine and $L$-isoleucine or by L-valine and L-isoleucine separately. Again the addition of L-valine and L-isoleucine, together or individually, did not reverse the inhibitory effect of actinonin.

This inability to reverse the growth inhibitory action of actinonin, particularly when essential metal ions were added, suggested that the hydroxamic acid residue is not part of the active site of the actinonin molecule. This idea was supported when an analogue of actinonin, $O$-benzylactinonin, in which the hydroxamic acid residue had been chemically blocked proved to be biologically active. The growth inhibitory action of this compound proved to be very small but was reproducible. When further analogues become available the position of the hydroxamic acid residue with respect to the active site of the molecule will be investigated further. 
The results presented here are compatible with the idea that the over-all grown inhibitory effect of actinonin is associated with RNA synthesis. This is supported by the inhibitory effect of the antibiotic on the total amount of RNA synthesized within the first $75 \mathrm{~min}$. of incubation in the presence of actinonin. Within this time total RNA, and protein synthesis together with growth is seen to be inhibited but the initial inhibitory effect is associated with RNA synthesis. Moreover, the pattern of infective centre formation obtained when actinonin is added or removed from the phage $ø \mathrm{E} /$ Bacillus subtilis 36 Io system during the latent period demonstrates two possible sites of antibiotic action with respect to time within the latent period. This fact is also compatible with the site of action being associated with RNA rather than DNA or protein synthesis. The activity of actinonin also resembles the pattern obtained when actinomycinD, a known inhibitor of DNA directed RNA synthesis, is used in the system instead of actinonin and does not resemble the patterns obtained in the system when the protein synthesis inhibitor, chloramphenicol or 5-aminoacridine, which is known to inhibit viral DNA synthesis, is used. Thus these results indicate that actinonin inhibits bacterial growth by interfering with total cellular RNA synthesis. However, the actual site of action of actinonin cannot be deduced from these results.

I am grateful to Professor W. D. Ollis (University of Sheffield) and Dr J. J. Gordon (Chemical Defence Experimental Establishment, Porton) for the gift of actinonin which was used in this work and to Mr D. J. Trott for technical assistance.

\section{REFERENCES}

Adams, M. H. (1959). Bacteriophages, p. 473. New York: Interscience Publishers Inc.

ArnsteIn, H. R. V. (1957). The biosynthesis of penicillin and some other antibiotics. Ann. Rep. Chem. Soc. Lond. 54, 339.

Burton, K. (1956). A study of the conditions and mechanisms of the diphenylamine reaction for the colorimetric estimation of deoxyribosenucleic acid. Biochem. J. 63, 315 .

Davis, B. D. \& MingIoli, E. S. (1960). Mutants of Escherichia coli requiring methionine or vitamin $\mathbf{B}_{\mathbf{1 2}}$. J. Bact. 60, 17.

Gale, E. F. \& TAYLOR, E. S. (1947). The assimilation of amino acids by bacteria. 2. The action of tyrocidin and some detergent substances in releasing amino acids from the internal environment of Streptococcus faecalis. J. gen. Microbiol. $\mathbf{1}, 77$.

Gordon, J. J., Kelly, B. K. \& Miller, G. A. (1962). Actinonin: an antibiotic substance produced by an actinomycete. Nature, Lond. 195, 701.

Goth, A. (1945). The antitubercular activity of aspergillic acid and its probable mode of action. J. Lab. clin. Med. 30, 899.

HogG, R. W., Biswas, C. S. \& Broquist, H. P. (1965). Interference with valine and isoleucine biosynthesis by cyclic hydroxamic acids. J. Bact. 90, 1265.

Lowry, O. H., Rosebrough, N. J., FARR, A. L., \& Randall, R. J. (I95I). Protein measurement with the Folin phenol reagent. J. biol. Chem. 193, 265.

Ollis, W. D., EAST, A. J., Gordon, J. J. \& SutherLAND, I. O. (1964). The constitution of actinoninstructural and synthetic studies. Institute of Applied Microbiology Symposium, no. 6, p. 204. Chemistry of Microbial Products.

SCHNEIDER, W. C. (1957). Determination of nucleic acids in tissues by pentose analysis. Meth. Enzymol. 3, 680 .

UMBreit, W. W., Burris, R. H. \& STAufFer, J. F. (1964). Manometric Techniques, 4th ed. Burgess Publishing Co. 